УДК 633.15:631.5

DOI 10.36461/NP.2020.57.4.018

\title{
ПРИЕМЫ АГРОТЕХНИКИ И БИОХИМИЧЕСКИЙ СОСТАВ КУКУРУЗЫ
}

С. А. Семина' Ю.А. Семина ${ }^{2}$ канд. с.-х. наук

1 Федеральное государственное бюджетное образовательное учреждение высшего образования «Пензенский государственный аграрный университет», г. Пенза, Россия, тел. 8(8412) 62-81-51; e-mail: seminapenza@rambler.ru

2Федеральное государственное бюджетное научное учреждение «Федеральный научный центр овощеводства», поселок ВНИИССОК, Одинцовский городской округ, Россия

В статье представлены результаты исследований влияния некорневой обработки посевов растворами комплексных удобрений с микроэлементами в хелатной форме Азосол 36 Экстра и Акварин 5 на биохимический состав и кормовую ценность биомассы раннеспелого и среднераннего гибридов кукурузы на различных уровнях корневого питания. Установлено, что на содержание сырого протеина большее влияние оказали минеральные удобрения: содержание сырого протеина в фитомассе раннеспелого гибрида кукурузы увеличилось в среднем на 1,65 \%, а среднераннего - на 1,76 \%. Положительное влияние на накопление сырого протеина оказала обработка посевов удобрениями с микроэлементами в фазу пяти листьев кукурузы и бинарное применение. При обработке посевов удобрением Акварин 5 отмечается уменьшение сырой клетчатки в фитомассе, а более эффективным было двукратное опрыскивание посевов. Фолиарная обработка комплексными удобрениями с микроэлементами способствовала увеличению содержания сырого жира на 0,10-0,34 \%. Какой-либо определенной закономерности в зависимости от вида микроудобрений по влиянию на зольность биомассы и содержание БЭВ не выявлено. На фоне естественного почвенного плодородия больший сбор переваримого протеина получен при двукратном применении микроэлементных удобрений, а на улучшенном агрофоне - при обработке посевов в фазу пяти листьев кукурузы. На обоих фонах минерального питания некорневая обработка Азосол 36 Экстра способствовала получению зеленой массы, лучше обеспеченной переваримым протеином, и выявлено преимущество обработки комплексными удобрениями в фразу пяти листьев и двукратного применения. При обработке посевов Азосол 36 Экстра прибавка кормовых единиц составила 8,1-10,1\%.

ключевые слова: кукуруза, гибрид, удобрения, микроэлементы, протеин, клетчатка, зола.

\section{Введение}

Кукуруза является одной из наиболее продуктивных и технологичных сельскохозяйственных культур. В России кукуруза получила широкое распространение как силосная культура. Кукурузный силос высокого качества играет важную роль в обеспечении рационального кормления животных. Поэтому определение в растениях концентрации и соотношения основных питательных веществ, их переваримости и усвояемости, имеет важное значение в современном кормопроизводстве. Чем больше в корме питательных веществ, тем выше его питательность. Но высокое содержание одного какого-либо питательного вещества не дает основание сделать заключение о высокой питательности корма вообще [1-3]. Растениям для полной реализации потенциала сорта или гибрида и формирования качественной продукции наряду с макроудобрениями, необходимо оптимальное снабжение микроэлементами. В современ- ных условиях возделывания сельскохозяйственных культур использование удобрений, содержащих микроэлементы, становится неотъемлемой частью технологии [4$6,19]$. Применение макро- и микроудобрений, наряду с повышением урожайности кукурузы, может оказывать влияние на качество растениеводческой продукции [7-10, 20]. Сегодня все большей популярностью у сельхозпроизводителей пользуются комплексные удобрения, содержащие помимо азота, фосфора и калия, целый спектр микроэлементов. Одним из путей решения проблемы, связанной с разработкой альтернативных подходов для улучшения минерального питания растений, может быть использование листовых подкормок комплексными удобрениями с микроэлементами в хелатной форме [11-13]. Эффрективность листовых подкормок кукурузы отмечали ряд исследователей [14-16, 21]. Листовые подкормки вегетирующих растений проявляют себя достаточно эффективно, если они 
проводятся своевременно и совпадают с критическими периодами роста и развития.

Поэтому комплексные исследования по изучению влияния вида и срока некорневой обработки комплексными удобрениями с микроэлементами в хелатной форме на биохимический состав и кормовую ценность зеленой массы кукурузы являются актуальными, что и определило цель исследования.

\section{Методы и материалы}

Исследования проводили в 2016-2018 гг. на черноземе выщелоченном тяжелосуглинистом с повышенным содержанием азота, фосфора и калия, реакция почвенного раствора слабокислая. Полевой опыт был заложен в соответствии с общепринятыми методиками [17-18] в четырехкратной повторности по схеме: фактор А - гибрид: раннеспелый Ладожский 191 МВ (ФАО 190), среднеранний Роналдинио (ФАО 210); фактор В - удобрение: 1. $\mathrm{N}_{0} \mathrm{P}_{0} \mathrm{~K}_{0}+$ обработка растений водой; 2. $\mathrm{N}_{0} \mathrm{P}_{0} \mathrm{~K}_{0}+$ Азосол 36 Экстра (3,0 л/га): 3. NoPoKo + Акварин 5 (3,0 л/га); 4. N $110 \mathrm{P}_{70} \mathrm{~K}_{40}+$ обработка растений водой; 5. $\mathrm{N}_{110} \mathrm{P}_{70} \mathrm{~K}_{40}+$ Азосол 36 Экстра; 6. $\mathrm{N}_{110} \mathrm{P}_{70} \mathrm{~K}_{40}+$ Акварин 5; фрактор C - срок некорневой обработки: 1. в фразу пяти листьев; 2. в фразу восьми листьев; 3. в фразу (пяти листьев $(3,0$ л/га) + восьми листьев $(3,0$ л/га). Расположение делянок первого и второго порядка систематическое, третьего рендомизированное. Площадь делянки третьего порядка $28 \mathrm{~m}^{2}$. Посев проводили с междурядьями 70 см. Густота стояния растений 80 тыс./га. Предшественник - озимая пшеница по чистому пару. Минеральные удобрения (аммиачная селитра, нитроаммофос, хлористый калий) в соответствии со схемой опыта вносили под первую предпосевную культивацию. Посев кукурузы проведен 18 мая в 2016 году, 27 мая в 2017 году и 18 мая в 2018 г. Уборка осуществлялась, соответственно, 1, 15 и 10 сентября. Комплексные удобрения с микроэлементами растворяли в воде (из расчета 200 л/га). Некорневую обработку посевов комплексными удобрениями выполняли с помощью ранцевого опрыскивателя.

Погодные условия в годы исследований значительно различались между собой. Погодные условия 2016 г. были достаточно благоприятными для роста и развития кукурузы (гидротермический коэффициент (ГТК) - 1,09), Гидротермические условия периода вегетации культуры в 2017 г. (ГТК = 0,98) были менее благоприятными. Вегетационный период 2018 г. характеризовался недостаточным количеством осадков на фроне пониженных температур воздуха $(Г К=0,40)$.

\section{Результаты}

Качество корма определяется содержанием питательных веществ (протеин, клетчатка, жир, безазотистые экстрактивные вещества, минеральные элементы и др.). Производство продукции животноводства в значительной мере зависит от решения белковой проблемы в растениеводстве. В результате трехлетних исследований установлено, что на содержание сырого протеина большее влияние оказали минеральные удобрения. В среднем по фрактору $\mathrm{B}$, при внесении полного минерального удобрения, содержание сырого протеина в фитомассе раннеспелого гибрида кукурузы увеличилось на 1,65 \%, а среднераннего на 1,76 \% (табл. 1). Выявлено, что на накопление белковых веществ значительное влияние оказали погодные условия периода вегетации. Менее обеспеченная белком фитомасса получена в относительно благоприятном 2016 г., когда в период уборки зерно в початках практически достигало восковой спелости. Содержание сырого протеина варьировало от 5,23-5,52 \% на неудобренном агрофоне до 6,12-6,44 \% - при внесении удобрений. При недостатке активных температур в 2017 г. сорормировалась более обеспеченная белком биомасса. Содержание сырого протеина изменялось от 7,19$7,61 \%$ на естественном агрофоне, до 9,03$11,13 \%$ - при улучшении условий корневого питания. В годы проведения опыта, как по изучаемым препаратам, так и срокам фолиарной обработки значительных различий не выявлено, однако, следует отметить, что и по видам препаратов, и по гибридам наибольшее положительное влияние на накопление сырого протеина оказала обработка посевов в фазу пяти листьев кукурузы и бинарное применение.

Сырая клетчатка в значительной степени определяет энергетическую питательность корма, содержание в нем полезных для животных органических веществ, способных к окислению. В рационах крупного рогатого скота ее должно быть минимум 16-18 \%. Но следует учитывать, что сырая клетчатка трудно переваривается и усваивается организмом. Большое количество клетчатки понижает питательную ценность растительного корма. Нашими исследованиями установлено, что больше сырой клетчатки содержалось в корме, полученном в 2017 г. - 27,19$31,06 \%$, а меньшим накоплением отличалась биомасса, выращенная в благоприятных условиях 2016 г. - 18,59-20,71 \%. Установлено, что при обработке посевов удобрением Акварин 5 прослеж-ивается уменьшение сырой клетчатки в фитомассе, а, значит, и увеличение переваримости корма. Эта 
тенденция прослеживается во все годы исследований для обоих гибридов. Более эффективным было двукратное опрыскивание посевов, способствующее снижению содержания сырой клетчатки в кукурузе.

Жиры имеют высокую калорийность и являются главным аккумулятором энергии в организме. Как подтверждают экспериментальные данные, во все годы исследований наибольшим содержанием жира отличались растения раннеспелого гибрида Ладожский 191 МВ. Применение комплексных удобрений с микроэлементами способ- ствовали повышению калорийности корма, содержание сырого жира увеличилось на 0,10-0,34 \%. Установлено, что в среднем за три года испытаний применение Акварин 5 и Азосол 36 Экстра на посевах раннеспелого гибрида было практически равноценным по влиянию на содержание сырого жира. Для среднераннего гибрида Роналдинио выявлено, что при опрыскивании посевов Акварин 5 на обоих уровнях корневого питания прослеживается тенденция большего накопления сырого жира по сравнению с Азосол 36 Экстра.

Таблица

Биохимический состав кукурузы, среднее за 2016-2018 г2.

\begin{tabular}{|c|c|c|c|c|c|c|c|}
\hline \multirow[b]{2}{*}{$\begin{array}{c}\text { Гибрид } \\
\text { (фактор А) }\end{array}$} & \multirow[b]{2}{*}{$\begin{array}{l}\text { Удобрение } \\
\text { (фактор В) }\end{array}$} & \multirow{2}{*}{ 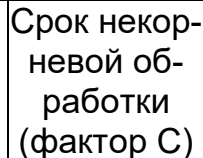 } & \multicolumn{5}{|c|}{ Содержание, \% в сухом веществе } \\
\hline & & & $\begin{array}{c}\text { сырой } \\
\text { протеин }\end{array}$ & $\begin{array}{c}\text { сырая } \\
\text { клетчатка }\end{array}$ & $\begin{array}{l}\text { сырой } \\
\text { жир }\end{array}$ & $\begin{array}{l}\text { сырая } \\
\text { зола }\end{array}$ & БЭВ \\
\hline \multirow{9}{*}{ 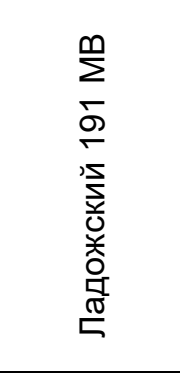 } & NPoKo + обработка водой & 5 лист & 6,54 & 24,94 & 2,08 & 3,66 & 63,09 \\
\hline & NoPoKo + обработка водой & 8 лист & 6,57 & 25,21 & 2,13 & 3,70 & 62,70 \\
\hline & $\mathrm{N}_{0} \mathrm{P}_{0} \mathrm{~K}_{0}+$ обработка водой & $5+8$ лист & 6,20 & 25,04 & 2,05 & 3,78 & 62,91 \\
\hline & $\mathrm{N}_{0} \mathrm{P}_{0} \mathrm{~K}_{0}+$ Азосол 36 Экстра & 5 лист & 6,49 & 24,91 & 2,38 & 3,77 & 62,43 \\
\hline & $\mathrm{N}_{0} \mathrm{P}_{0} \mathrm{~K}_{0}+$ Азосол 36 Экстра & 8 лист & 6,51 & 24,79 & 2,30 & 3,96 & 62,43 \\
\hline & $\mathrm{N}_{0} \mathrm{P}_{0} \mathrm{~K}_{0}+$ Азосол 36 Экстра & $5+8$ лист & 6,51 & 24,71 & 2,09 & 3,87 & 62,80 \\
\hline & $\mathrm{N}_{0} \mathrm{P}_{0} \mathrm{~K}_{0}+$ Акварин 5 & 5 лист & 6,32 & 24,78 & 2,26 & 3,77 & 62,86 \\
\hline & $\mathrm{N}_{0} \mathrm{P}_{0} \mathrm{~K}_{0}+$ Акварин 5 & 8 лист & 6,34 & 25,11 & 2,26 & 3,70 & 62,60 \\
\hline & $\mathrm{N}_{0} \mathrm{P}_{0} \mathrm{~K}_{0}+$ Акварин 5 & $5+8$ лист & 6,42 & 24,50 & 2,28 & 3,88 & 62,90 \\
\hline \multirow{9}{*}{ 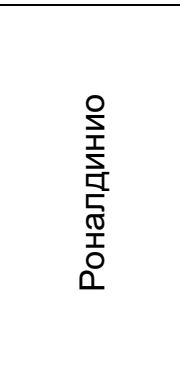 } & $\mathrm{N}_{0} \mathrm{P}_{0} \mathrm{~K}_{0}+$ обработка водой & 5 лист & 6,21 & 25,26 & 2,03 & 3,69 & 62,79 \\
\hline & №PoKo + обработка водой & 8 лист & 6,25 & 25,46 & 2,03 & 3,75 & 62,49 \\
\hline & $\mathrm{N}_{0} \mathrm{P}_{0} \mathrm{~K}_{0}+$ обработка вс & $5+8$ лист & 6,22 & 24,87 & 2,01 & 3,67 & 63,21 \\
\hline & $\mathrm{N}_{0} \mathrm{P}_{0} \mathrm{~K}_{0}+$ Азосол 36 Экстра & 5 лист & 6,40 & 24,92 & 2,14 & 3,72 & 62,80 \\
\hline & $\mathrm{N}_{0} \mathrm{P}_{0} \mathrm{~K}_{0}+$ Азосол 36 Экстра & 8 лист & 6,37 & 25,17 & 2,03 & 3,81 & 62,60 \\
\hline & $\mathrm{N}_{0} \mathrm{P}_{0} \mathrm{~K}_{0}+$ Азосол 36 Экстра & $5+8$ лист & 6,46 & 25,04 & 2,11 & 3,78 & 62,59 \\
\hline & $\mathrm{N}_{0} \mathrm{P}_{0} \mathrm{~K}_{0}+$ Акварин 5 & 5 лист & 6,42 & 25,10 & 2,15 & 3,88 & 62,43 \\
\hline & $\mathrm{N}_{0} \mathrm{P}_{0} \mathrm{~K}_{0}+$ Акварин 5 & 8 лист & 6,40 & 24,88 & 2,16 & 4,18 & 62,36 \\
\hline & $\mathrm{N}_{0} \mathrm{P}_{0} \mathrm{~K}_{0}+$ Акварин 5 & $5+8$ лист & 6,46 & 24,67 & 2,13 & 3,89 & 62,84 \\
\hline \multirow{9}{*}{ 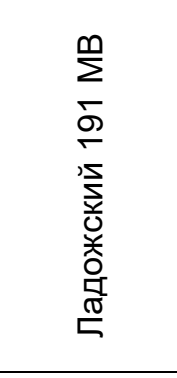 } & $\mathrm{N}_{110} \mathrm{P}_{70} \mathrm{~K}_{40}+$ обработка в & 5 лист & 7,87 & 22,95 & 2,28 & 3,68 & 63,47 \\
\hline & $\mathrm{N}_{110} \mathrm{P}_{70} \mathrm{~K}_{40}+$ обработка водой & 8 лист & 7,62 & 22,82 & 2,23 & 3,59 & 63,72 \\
\hline & $\mathrm{N}_{110} \mathrm{P}_{70} \mathrm{~K}_{40}+$ обработка водой & $5+8$ лист & 7,65 & 23,13 & 2,52 & 3,63 & 63,05 \\
\hline & $\mathrm{N}_{110} \mathrm{P}_{70} \mathrm{~K}_{40}+$ Азосол 36 Экстра & 5 лист & 8,63 & 22,57 & 2,59 & 3,67 & 62,86 \\
\hline & $\mathrm{N}_{110} \mathrm{P}_{70} \mathrm{~K}_{40}+$ Азосол 36 Экстра & 8 лист & 8,25 & 23,14 & 2,38 & 3,86 & 62,35 \\
\hline & $\mathrm{N}_{110} \mathrm{P}_{70} \mathrm{~K}_{40}+$ Азосол 36 Экстра & $5+8$ лист & 8,59 & 22,14 & 2,57 & 3,80 & 62,88 \\
\hline & $\mathrm{N}_{110} \mathrm{P}_{70} \mathrm{~K}_{40}+$ Акварин 5 & 5 лист & 8,12 & 21,99 & 2,58 & 3,82 & 63,48 \\
\hline & $\mathrm{N}_{110} \mathrm{P}_{70} \mathrm{~K}_{40}+$ Акварин 5 & 8 лист & 7,82 & 22,85 & 2,48 & 3,95 & 62,87 \\
\hline & $\mathrm{N}_{110} \mathrm{P}_{70} \mathrm{~K}_{40}+$ Акварин 5 & $5+8$ лист & 8,17 & 22,38 & 2,55 & 3,91 & 62,97 \\
\hline \multirow{9}{*}{ 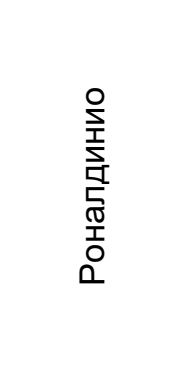 } & $\mathrm{N}_{110} \mathrm{P}_{70} \mathrm{~K}_{40}+$ обработка водой & 5 лист & 7,78 & 24,29 & 2,14 & 3,80 & 61,97 \\
\hline & $\mathrm{N}_{110} \mathrm{P}_{70} \mathrm{~K}_{40}+$ обратка водой & 8 лист & 7,82 & 24,44 & 2,04 & 3,91 & 61,77 \\
\hline & $\mathrm{N}_{110} \mathrm{P}_{70} \mathrm{~K}_{40}+$ обработка водой & $5+8$ лист & 7,80 & 24,50 & 2,10 & 3,82 & 61,76 \\
\hline & $\mathrm{N}_{110} \mathrm{P}_{70} \mathrm{~K}_{40}+$ Азосол 36 Экстра & 5 лист & 8,27 & 23,96 & 2,31 & 3,88 & 61,56 \\
\hline & $\mathrm{N}_{110} \mathrm{P}_{70} \mathrm{~K}_{40}+$ Азосол 36 Экстра & 8 лист & 8,26 & 25,13 & 1,82 & 4,08 & 60,38 \\
\hline & $\mathrm{N}_{110} \mathrm{P}_{70} \mathrm{~K}_{40}+$ Азосол 36 Экстра & $5+8$ лист & 8,51 & 23,19 & 2,39 & 3,91 & 61,98 \\
\hline & $\mathrm{N}_{110} \mathrm{P}_{70} \mathrm{~K}_{40}+$ Акварин 5 & 5 лист & 8,23 & 23,02 & 2,42 & 3,96 & 62,35 \\
\hline & $\mathrm{N}_{110} \mathrm{P}_{70} \mathrm{~K}_{40}+$ Акварин 5 & 8 лист & 8,02 & 23,88 & 2,29 & 3,96 & 61,83 \\
\hline & $\mathrm{N}_{110} \mathrm{P}_{70} \mathrm{~K}_{40}+$ Акварин 5 & $5+8$ лист & 8,33 & 23,43 & 2,44 & 4,00 & 61,79 \\
\hline
\end{tabular}


В состав сырой золы входят как макро, так и микроэлементы. Как показали проведенные исследования по содержанию сырой золы, не выявлено какой-либо четкой закономерности в зависимости от срока применения и вида удобрения. Отмечена лишь тенденция увеличения зольности биомассы при некорневой обработке растений микроэлементными удобрениями, по сравнению с обработкой водой.

Безазотистые экстрактивные вещества (БЭВ) относятся к легкопереваримым углеводам. По годам исследований отмечено значительное варьирование этого показателя качества биомассы. В условиях 2016 г. в сухой биомассе содержание БЭВ составило $67,40-68,13$ \% и мало изменялось в зависимости от гибрида и приемов агротехники. В 2017 г. оно было значительно меньше - 55,31-58,83 \% и отмечено снижение БЭВ на фоне улучшенного корневого питания. Какой либо определенной закономерности в зависимости от вида микроудобрений не выявлено. В 2018 г. при внесении полного минерального удобрения отмечена тенденция роста БЭВ в биомассе раннеспелого гибрида, по сравнению с естественным агрофоном, а для среднераннего гибрида прослеживается обратная закономерность. Двукратная обработка комплексными удобрениями способствовала небольшому приросту БЭВ, по сравнению с водой. Но, в среднем за годы исследований, значимых различий, как по уровням корневого питания, так и по видам микроэлементных удобрений, не выявлено.

Максимальный в опыте сбор переваримого протеина (ПП), как на удобренном, так и неудобренном агрофонах, получен на посевах среднераннего гибрида (рис.).

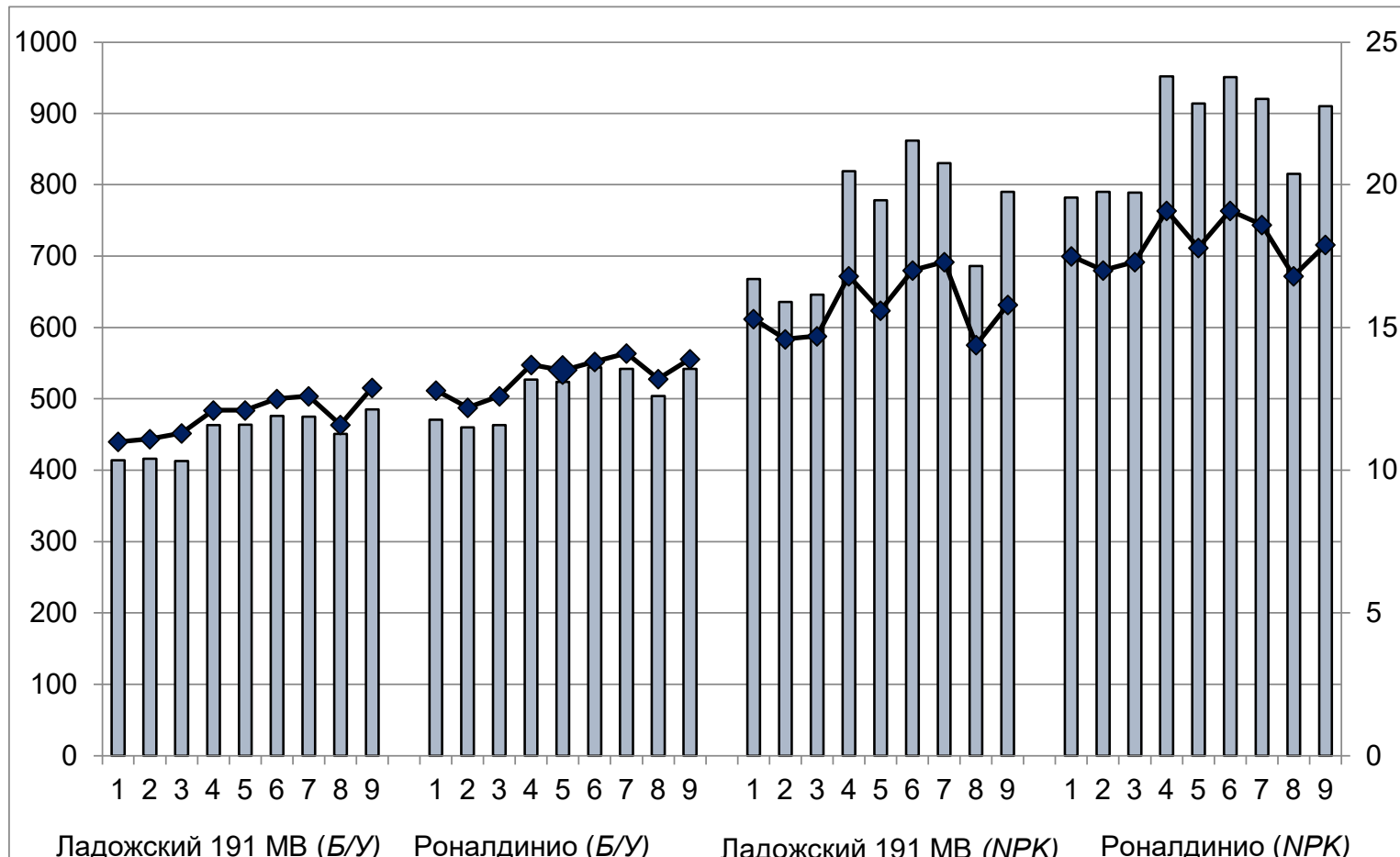

Ладожский 191 MB (Б/У) Роналдинио (Б/У) Ладожский 191 MB (NPK) Роналдинио (NPK)

己Сбор переваримого протеина, кг/га $\neg$ —Выход кормовых единиц, т/га

Рис. Кормовая питательность кукурузы, среднее за 2016-1018 ге.

Примечание: фактор А - гибрид: раннеспелый Ладожский 191 МВ, среднеранний Роналдинио; фрактор В - удобрение; фрактор C - срок обработки: 1 - обработка водой (5 лист); 2 - обработка водой (8 лист); 3 - обработка водой (5+8 лист); 4 - Азосол 36 Экстра (5 лист); 5 - Азосол 36 Экстра (8 лист); 6 - Азосол 36 Экстра (5+8 лист); 7 - Акварин 5 (5 лист); 8 - Акварин 5 (8 лист); 9 - Акварин 5 (5+8 лист)

В основном это объясняется большей урожайностью сухого вещества среднераннего гибрида. На фоне естественного почвенного плодородия больший сбор протеина получен при двукратном применении микроэлементных удобрений, а при внесении минеральных удобрений - преимущество за фолиарной обработкой посевов в фразу пяти листьев кукурузы. На неудобренном агрофоне при некорневой обработке раннеспелого гибрида Азосол 36 Экстра обеспеченность кормовой единицы 
переваримым протеином увеличилась на $2,7 \%$, а от Акварин 5 - на 2,2 \%. Для среднераннего гибрида прибавки составили 4,9 и 3,9 \% соответственно микроэлементным удобрениям. На улучшенном уровне корневого питания обеспеченность кормовой единицы ПП при обработке водой увеличилась по сравнению с естественным плодородием на 17,4 и 22,9 \% соответственно гибридам. Обработка посевов раннеспелого гибрида Азосол 36 Экстра в дополнение к внесению полного минерального удобрения повышала обеспеченность кормовой единицы ПП до 49,77 г или на 13,8 \%, по сравнению с обработкой водой. От применения Акварин 5 на удобренном агрофоне прирост в полтора раза меньше. Фолиарная обработка Азосол 36 Экстра в условиях улучшенного корневого питания позволила увеличить протеиновую обеспеченность кормовой единицы среднераннего гибрида Роналдинио на $10,4 \%$, а от опрыскивания Акварин 5 прибавка составила 4,02 г или 8,8 $\%$, по сравнению с водой. Выход кормовых единиц при внесении минеральных удобрений в среднем увеличился на 3,8-5,0 т/га или 34,2-36,5 \% (рис.). Наибольшие прибавки среди изучаемых удобрений с микроэлементами на всех агрофонах обеспечила обработка Азосол 36 Экстра - 8,1-10,1 \%, причем как абсолютные, так и относительные прибавки были выше на фоне естественного почвенного плодородия.
Кукуруза является высокоэнергетическим кормом. Как свидетельствуют полученные результаты, в год исследования получена биомасса с содержанием обменной энергии 10,4-11,0 МДж/кг сухого вещества и положительного влияния комплексных удобрений на энергообеспеченность корма не выявлено.

\section{Заключение}

Таким образом, полученные результаты свидетельствуют, что как по видам препаратов, так и по гибридам большее влияние на накопление сырого протеина оказало применение комплексных удобрений с микроэлементами в фазу пяти листьев кукурузы и бинарная обработка. При фолиарной обработке удобрением Акварин 5 прослеживается уменьшение сырой клетчатки в биомассе кукурузы, а более эффективным было двукратное опрыскивание посевов. Применение комплексных удобрений с микроэлементами способствовало увеличению содержания сырого жира на 0,10$0,34 \%$. На фоне естественного почвенного плодородия больший сбор протеина получен при двукратном применении микроэлементных удобрений, а при улучшении корневого питания - преимущество за фолиарной обработкой посевов в фазу пяти листьев кукурузы. Наибольшие прибавки кормовых единиц на всех агрофонах обеспечила обработка Азосол 36 Экстра - 8,1$10,1 \%$, по сравнению с водой.

\section{Лumepamypa}

1. Богданов Г.А. Кормление сельскохозяйственных животных: учебное пособие. Москва: Агропромиздат, 1990, 624 с.

2. Макарцев Н. Г. Кормление сельскохозяйственных животных: учебник для вузов. Калуга: Ноocopepa, 2012, 640 c.

3. Надточаев Н.Ф., Абрамова С.В. Как получить качественный кукурузный силос. Белорусское сельское хозяйство, 2005, № 9, с. 22-26.

4. Лапа В.В., Смольский В.Г. Динамика формирования биомассы кукурузы в зависимости от применения азотных, цинковых и магниевых удобрений. Приемы повышения плодородия почв, эффрективности удобрений и средств защиты растений: материалы международной научно-практической конференции. Белорусская государственная сельскохозяйственная академия, Горки, 2003, ч. 2, с. 188-192.

5. Гайсин И. А. Сагитова Р.Н., Хабибуллин Р.Р. Микроудобрения в современном земледелии. Агрохимический вестник, 2010, № 4, с. 13-14.

6. Васин В.Г., Саниев Н.Р., Васин А.В., Бурунов А.А., Просандеев Н.А., Трифонов Д.И. Применение микроудобрительных смесей и биопрепаратов при возделывании сои. Агрохимический вестник, 2019, № 2, с. 47-52.

7. Труфанова А.А., Сорокина О.А. Действие удобрений при некорневых подкормках и внутрипочвенном внесении на урожайность яровой пшеницы и химический состав зерна. Вестник КрасГАУ, 2013, № 5, с. 108-113.

8. Моисеев А.А., Ивойлов А.В., Сидоров А.В., Власов П.Н. Эффективность удобрений при возделывании кукурузы на зерно в условиях Южного Нечерноземья: монография. Саранск: Издательство Мордовского университета, 2018, 172 с.

9. Смольский В.Г. Влияние жидких комплексных удобрений на основе КАС на урожайность и качество зеленой массы кукурузы: диссертация на соискание ученой степени кандидата с.-х. наук: 06.01.04. Минск, 2004, 108 с. 
10. Скарга О.В., Толорая Т.Р., Малаканова В.П. [и др.]. Обработка микроэлементами семян гибридов и самоопыленных линий кукурузы. Кукуруза и сорго, 2004, № 1, с. 2-4.

11. Гейгер Е.Ю., Варламова Л.Д., Семенов В.В., Погодина Ю.В., Сиротина Ю.А. Микроудобрения на хелатной основе: опыт и перспективы использования. Агрохимический вестник, 2017, № 2, с. 29-32.

12. Закиров Э.Ш., Сагитова Р.Н., Гайсин И.А., Тихонова М.А. Влияние хелатных микроудобрений на качественные характеристики растениеводческой продукции. Агрохимический вестник, 2014, № 4, с. 9-13.

13. Рак М.В., Кляусова Е.В. Влияние некорневых подкормок микроудобрениями на качество зеленой массы и зерна кукурузы. Почвоведение и агрохимия, 2013, № 2(51), с. 221-228.

14. Таран Д.А., Ломовский Д.В., Вакуленко И.Н. Повышение продуктивности гибридов кукурузы рациональным применением аммиачной селитры при посеве и в подкормку гуматом калия. Научное обеспечение агропромышленного комплекса: материалы 5-ой Всероссийской научно-практической конференции молодых ученых. Краснодар, 2011, с. 122-123.

15. Дзанагов С.Х., Езеев А.А., Фарниев А.Т. Динамика накопления биомассы и химический состав растений кукурузы в зависимости от удобрений. Известия Горского государственного аграрного университета, 2013, т. 50, № 2, с. 36-40.

16. Семина С.А., Гаврюшина И.В. Приемы возделывания и биохимический состав кукурузы. Агропромышленный комплекс: состояние, проблемы, перспективы: материалы XIII Международной научно-практической конференции. Пенза, 2017, с.158-160.

17. Доспехов Б.А. Методика опытного дела (с основами статистической обработки результатов). Москва: Агропромиздат, 1985, 351 с.

18. Методические рекомендации по проведению полевых опытов с кукурузой. Днепропетровск, 1980, 54 с.

19. Welch R.M., Graham R.M. Agriculture: the real nexus for enhancing bioavailable micronutrients in food crops. Journal of Trace Elements in Medicine and Bilogy, 2005, № 18, p. 299-307.

20. Semina S.A., Gavryushina I.V. The formation of the quality of maize, depending on the density of plants and fertilizers. Research Journal of Pharmaceutical, Biological and Chemical Sciences, 2018, v. 9, № 2, p. 650-655.

21. Fernandez V., Ebert G. Foliar iron fertilization: A critical review. Journal of Plant Nutrition, 2005, № 28, p. 2113-2124.

UDC 633.15:631.5

DOI 10.36461/NP.2020.57.4.018

\title{
AGRICULTURAL TECHNIQUES AND BIOCHEMICAL COMPOSITION OF CORN
}

\author{
S.A. Semina1, Doctor of Agricultural Sciences, Professor; \\ I.V. Gavryushina ${ }^{1}$, Candidate of Biological Sciences, Associate Professor; \\ Yu.A. Semina², Candidate of Agricultural Sciences \\ ${ }^{1}$ Federal State Budgetary Educational Institution of Higher Education "Penza State Agrarian \\ University", Penza, Russia, tel. 8(8412) 62-81-51; e-mail: seminapenza@rambler.ru \\ ${ }^{2}$ Federal State Budgetary Scientific Institution "Federal Scientific Center of Vegeculture", \\ VNIISSOK settlement, Odintsovo city district, Russia.
}

The article presents the research results of the influence of foliar treatment with solutions of complex fertilizers with microelements in chelated form (Azosol 36 Extra and Aquarin 5) on the biochemical composition and feeding value of biomass in early-season and middle-early corn hybrids at different levels of root nutrition. It was found that the content of crude protein was more influenced by mineral fertilizers: the content of crude protein in the phytomass of early-season hybrid corn increased by an average of $1.65 \%$, and the middle-early - by $1.76 \%$. A positive effect on the crude protein accumulation was provided by the treatment of crops with fertilizers with microelements in the five-leaf phase of corn and binary application. When treating crops with Aquarin 5 fertilizer, there was a decrease of crude fibre in the phytomass; the double crop spraying was more effective. Foliar treatment with the complex fertilizers with microelements contributed to an increase in the crude fat content by $0.10-0.34 \%$. No specific pattern was found, depending on the type of microfertilizers, on the effect on the biomass ash-content and the nitrogen-free extractive substances (NFE) content. Against the background of natural soil fertility, a greater collection of digestible protein was obtained 
with a double application of microelement fertilizers, and against the improved agricultural background - with the treatment of crop in the five-leaf phase of corn. Against both backgrounds of mineral nutrition, foliar treatment with Azosol 36 Extra contributed to obtaining a green mass better provided with digestible protein; and the advantage of treatment with complex fertilizers in the five-leaf phase and the double application was revealed. When treating crops with Azosol 36 Extra, the increase in feed units was 8.1-10.1\%.

Keywords: corn, hybrid, fertilizers, microelements, protein, fibre, ash.

\section{References}

1. Bogdanov, G.A. Feeding farm animals: a textbook. Moscow: Agropromizdat, 1990, 624 p. $640 \mathrm{p}$

2. Makartsev N.G. Feeding farm animals: a textbook for universities. Kaluga: Noosphera, 2012,

3. Nadtochaev N.F., Abramova S.V. How to get high-quality corn silage. Belorusskoe selskoe hozyaystvo, 2005, No. 9, pp. 22-26.

4. Lapa V.V., Smolsky V.G. Dynamics of corn biomass formation depending on the use of nitrogen, zinc and magnesium fertilizers. Techniques for improving soil fertility, the effectiveness of fertilizers and plant protection products: materials of the international scientific and practical conference. Belarusian State Agricultural Academy, Gorki, 2003, part 2, pp. 188-192.

5. Gaisin I. A. Sagitova R.N., Khabibullin R.R. Microfertilizers at modern agriculture. Agrochemical Herald, 2010, no. 4, pp. 13-14.

6. Vasin V.G., Saniev R.N., Vasin A.V., Burunov A.N., Prosandeev N.A., Trifonov D.I. Microfertilizers and biopreparations application for soya cultivation. Agrochemical Herald, 2019, No. 2, pp. 47-52.

7. Trufanova A.A., Sorokina O.A. Fertilizer effect of non-root additional fertilizers and intra soil introduction on spring wheat productivity and the grain chemical composition. The Bulletin of KrasGAU, 2013, No. 5, pp. 108-113.

8. Moiseev A.A., Ivoilov A.V., Sidorov A.V., Vlasov P.N. Efficiency of fertilizers in the cultivation of corn for grain in the conditions of the Southern Non-Chernozem region: a monograph. Saransk: Publishing house of the Ogarev Mordovia State University, 2018, 172 p.

9. Smolsky V.G. The influence of liquid complex fertilizers based on UAN on the yield and quality of the green mass of corn: dissertation for the degree of the Candidate of Agricultural Sciences: 06.01.04. Minsk, 2004, $108 \mathrm{p}$.

10. Skarga O.V., Toloraya T.R., Malakanova V.P. [et al.]. Microelement treatment of seeds of hybrids and selfd corn lines. Kukuruza i sorgo, 2004, No. 1, pp. 2-4.

11. Geiger E.Yu., Varlamova L.D., Semenov V.V., Pogodina Yu.V., Sirotina Yu.A. Chelated microfertilizers: experience and prospects of use. Agrochemical Herald, 2017, no. 2, pp. 29-32.

12. Zakirov E.Sh., Sagitova R.N., Gaisin I.A., Tikhonova M.A. Influence of chelate microfertilizers on yield and quality of plant production. Agrochemical Herald, 2014, no. 4, pp. 9-13.

13. Rak M.V., Kliausova Y.V. Influence of outside root top- dressing by microfertilizers on green mass and grain corn quality. Soil Science and Agrochemistry, 2013, no. 2(51), pp. 221-228.

14. Taran D.A., Lomovsky D.V., Vakulenko I.N. Increasing the productivity of corn hybrids by rational use of ammonium nitrate for planting and fertilizing with potassium humate. Scientific support of the agro-industrial complex: materials of the 5th All-Russian Scientific and Practical Conference of Young Scientists. Krasnodar, 2011, pp. 122-123.

15. Dzanagov S.Kh., Ezeev A.A., Farniev A.T. Dynamics of biomass accumulation and chemical composition of corn plants depending on fertilizers. Proceedings of Gorsky State Agrarian University, 2013, vol. 50, no. 2, pp. 36-40.

16. Semina S.A., Gavryushina I.V. Methods of cultivation and biochemical composition of corn. Agro-industrial complex: state, problems, prospects: materials of the XIII International Scientific and Practical Conference. Penza, 2017, pp. 158-160.

17. Dospekhov B.A. The methodology of the experimenting (with the basics of statistical processing of the results). Moscow: Agropromizdat, 1990, $624 \mathrm{p}$.

18. Methodological recommendations for conducting field experiments with corn. Dnepropetrovsk, $1980,54 \mathrm{p}$.

19. Welch R.M., Graham R.M. Agriculture: the real nexus for enhancing bioavailable micronutrients in food crops. Journal of Trace Elements in Medicine and Bilogy, 2005, № 18, p. 299-307.

20. Semina S.A., Gavryushina I.V. The formation of the quality of maize, depending on the density of plants and fertilizers. Research Journal of Pharmaceutical, Biological and Chemical Sciences, 2018, v. 9, № 2, p. 650-655.

21. Fernandez V., Ebert G. Foliar iron fertilization: A critical review. Journal of Plant Nutrition, 2005, № 28, p. 2113-2124. 